Arch. hist. jap. Vol. 13, n. 4 (December 1957).

P. $487-490$.

Dept. of Anat., Kyoto Prefectural Med. College (Director: Prof. Dr. H. NODA).

\title{
Histochemical Studies on the Hypothalamo-hypophysial Neurosecretory System. \\ II. PAS Reaction in the Freeze-dried Section*.
}

(Contributions to the Comparative Histology of the

Hypothalamo-hypophysial System. 37th report.)

視床下部下垂体神経分泌系の組織化学的研究.

II. 谏結㲦燥標本飞怙ける PAS 反応.

(視床下部下垂体系の比較組織学的研究。第 37 報.)

Teruo IMOTO 井 本 昭 雄.

(Received October 17, 1957.)

Previous paper (9th report, 1955) presented by the author reported on the distribution and the specific verification of PAS-positive substance in the paraffine section of the tissue fixed with formalin. With application of the freezing drying method, distribution of polysaccharide in the hypothalamo-hypophyseal system was further investigated and it is the wish of the author to present in this paper the current findings thus obtained.

\section{Material and Method.}

Three adult dogs were used. Freeze-dried paraffin sections were prepared according to the NAKAJIMA, TSUJII and NAORA's method (1950). The hypothalamo-hypophyseal system obtained from the animal killed by bleeding was made into tissue blocks of $3 \times 3 \times 1.5 \mathrm{~mm}^{3}$. The tissue blocks were laid on a copper mesh, and immediately immersed into the freezing mixture of acetone-dryice $\left(-75^{\circ} \mathrm{C}\right)$ where they were frozen instantly. After approximately 30 minutes the tissue blocks were transfered into the drying paraffine infiltrating apparatus kept at temperature from $-60^{\circ} \mathrm{C}$ to $-70^{\circ} \mathrm{C}$, where the tissues were to be dehydrated by means of evacuation. After evacuating for an hour as it is, the temperature in the apparatus was gradually raised to become $-30^{\circ} \mathrm{C}$ in about 2 hours. And the dehydration was continued for 26 hours under constant pressure, the degree of vacuum being maintained at $10^{-4} \mathrm{~mm} \mathrm{Hg}$ as observed constantly through GEISSLER's tube and the vacuum gauge. After dehydration was thus carried out, the temperature in the apparatus was gradually raised and in 3 hours was brought to room temperature. Embedding was comleted with paraffine previously prepared in the apparatus under

* The author wishes to thank Assist.-Prof. Dr. M. Yamada, Dept. of Anat., Nara Medical College, and Prof. Dr. Y. Fujiki, Dept. of Physics, Kyoto Prefectural Medical College, for much valuable help given by them during the course of this study. 
this low pressure. Sections ( $8 \mu$ in thickness) were, directly or with use of water or $80 \%$ alcohol, spread on slide glasses slightly coated with egg-white glycerine, and the PAS procedure was performed.

\section{Observations and Consideration.}

State of dehydration of tissue blocks of both the hypothalamus and hypophysis seemed to be satisfactory as observed through the infiltrating condition of the paraffine. However, in sections stained with hematoxylin-eosin, the cytoplasm of the majority of the nerve cells in supraoptic nucleus was found to be more or less modified, showing honey-comb like figures. This is believed to be an artefact to have resulted from the formation of ice crystal in the cytoplasm, due to the temperature being rather high at the time of freezing. In sections of supraoptic nucleus in which the PAS reaction was carried out, many neurosecretory cells could be observed with positive granules stained purple red distributed evenly in the cytoplasm.

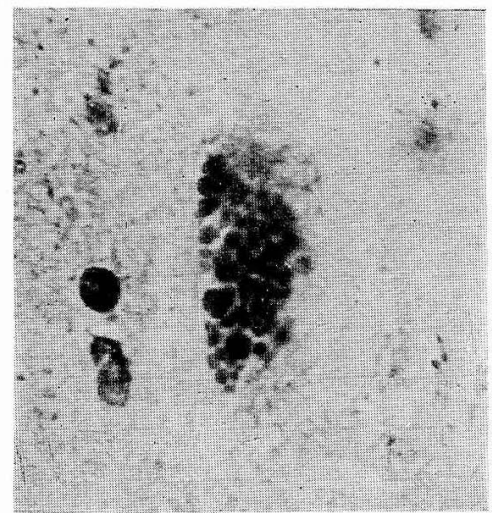

a

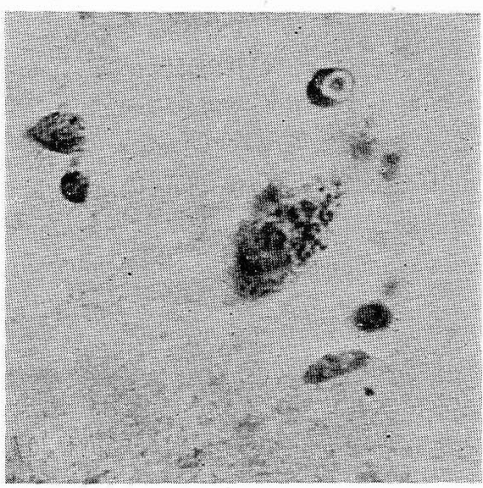

$\mathrm{b}$

Fig. 1. PAS reaction of a neurosecretory cell in the supraoptic nucleus of a dog. a $\times 812$, b $\times 541.8 \mu$ paraffine section by freeze-drying method.

However, formless PAS positive substance could not be observed in any of the nerve cells. The size of intracytoplasmic granules was found to be variable, some extremely small to some as large as to form a droplet. The number of the granules in the cytoplasm was also found to be variable. Positive substances obtained by freezing drying mcthod were always found to be granular and no such instance occurred. where they were found to be diffuse and formless. In some of the neurosecretory cells, no positive granules could be observed.

State of dehydration of the posterior lobe was found to be satisfactory and in no cases was technical destruction of tissues observed. From the 'Zwischenstück' (infundibular stem) to the posterior lobe, PAS-positive substances were observed as in GOMORI staining section, the substances being of granular form and abundant in quantity. The distribution of the PAS positive substances was found to be identical to that of the neurosecretory material. The substance was observed to be especially grouped together at the peripheral part of the posterior lobe and around the blood 


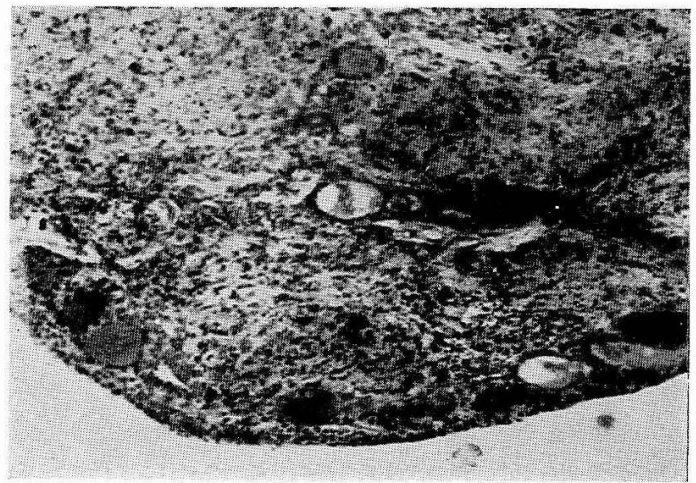

a

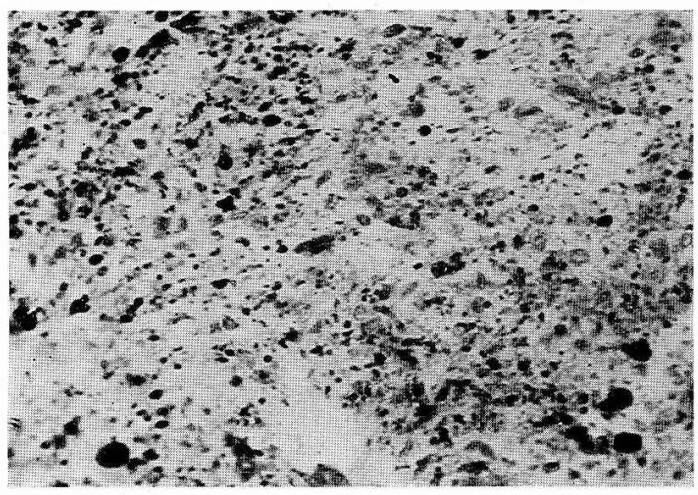

b

Fig. 2. PAS reaction of the posterior pituitary lobe of a dog. $\mathbf{a} \times 32$,

b $\times 326 . \quad 8 \mu$ paraffine section by freeze-drying method.

vessels (so-called 'Verdichtungszone'). In the ' $Z$ wischenstück' and the ' $Z$ wischenstreifen' (dispersed continuation in the posterior lobe of the former), the substances were observed corresponding to the course of nerve fibers, showing a linear arrangement. HERRING's bodies were also found to present a beautiful purple red reaction. And, HERRING's bodies were found to be of 2 types. One group was observed to react as a rounded homogenous mass of positive substances and the other group was found to react as a grouping of small positive granules. Such findings are found to be similiar to those observed in sections of GOMORI staining, azan staining or HEIDENHAIN's iron-hematoxylin staining.

The author has previously made report on PAS reaction in paraffine section of tissues fixed in ZENKER's fluid, BOUIN's fluid, absolute alcohol or formalin. Even though the neurosecretory cells and the HERRING's bodies were stained pink by means of these methods, the results were considered not to be satisfactory but inconclusive when consideration was made whether the findings were identical to those obtained with GOMORI's CH-P method. Hence, even if the neurosecretory material is believed to be a glyco-lipo-protein complex, conclusive evidence as to 
the weight of polysaccharide as a constitutional element of the complex was not to be obtained from the results reported in the author's previous paper.

HOWE and PEARSE (1956), from similar studies without application of the freeze-drying method, believes that the PAS-positive carbohydrate is not a component of the neurosecretory material. However, the findings obtained here, especially in the posterior lobe, with appliance of the freeze-drying method gives sufficient evidence proving PAS-positive substance to be an important component of the neurosecretory material.

\section{Summary.}

After carrying out PAS reaction on freeze-dried paraffine section of the hypothalamus and posterior lobe of adult dog, the distribution of positive substance was observed to be identical to that of the gomoriphil substance. These results assure that the PAS positive substance is a component of the neuroseretory material.

\section{内 容 自 抄。}

第 9 報に括いて視床下部下垂体系の普通標本に挌ける PAS 反応の所見を記載 したが，陽性物質と CH 好性神経分泌物の両者の同定がそれらの分布状態よりみ て稍々不充分であった点にかんがみ，その後行った視床下部及び下垂体の凍結乾 燥標本 (中島, 辻井, 直良氏法) に括ける同反応の所見について報告した。 この場 合は PAS 陽性物質の分布は正しくGomori 氏法標本に括ける神経分泌物のとれと 一致し，陽性物質が明らかと神経分泌物の構成要素であることが認められた。

\section{References.}

Howe, A. a. A. G. E. Pearse: J. Histochem. a. Cytochem. 4 (1956). P. 561. - Imoto, T.: (Jap. with German abstr.) Arch. hist. jap. 8 (1955). S. 361. — Nakajima, M., T. Tsujii a. H. Naora : (Jap.) Kagaku 20 (1950). P. 204. 